\title{
THE DEVELOPMENT AND IMPROVEMENT OF THE QUALITY SYSTEM OF AUDIT SERVICES IN LATVIA
}

\author{
LUDMILA VEROVSKA ${ }^{1}$
}

Baltic International Academy (Latvia)

\begin{abstract}
Audit activity is a variety of service industries, and cannot be developed independently of the major trends in this area. A strategic direction in the development of audit is creation of the international market of auditing services with unified rules and standards regulating audit, and creation of uniform quality criteria. This article examines the concept of quality audit service, analyzes the main problems of legislative and methodological character in the area of external and internal audit control in Latvia, and considers opportunities and ways of improvement based on international experience. The research results can be applied to construction and development of the systems of external and internal audit control, which will be providing the most reliable information about the state of business of companies-customers, their performance and prospects for sustainable development. The financial stability of a company, confirmed by the independent, objective opinion of an auditor, increases the growth of investments, the price of shares, improves the company's reputation in the financial market and ultimately contributes to the stable development of a region.

KEYWORDS: quality system of audit, quality requirements, criteria, internal and external quality control.
\end{abstract}

JEL CODES: M42; M41; D63

\section{Introduction}

Today the issue of quality audit services becomes increasingly important. The conditions of crisis increase the information risk, which becomes more dynamic. Users of financial documentation are placing ever greater demands on its accuracy, timeliness and transparency. In these circumstances, more and more attention is paid to the efficiency of the system of control over the quality of auditing services at both international and national levels. In Latvia, the mechanism of auditing services quality control at the public and professional levels is still at early stages of development, but important measures have been taken in the area of legislation. The legislation has established requirements to the organization of the system of audit quality control at the public and professional levels, and at the level of commercial auditor companies as well, alongside with the mandatory requirement to conduct quality assurance examinations of audit firms and individual auditors. However, up to date, a methodological basis of audit quality control has not been developed sufficiently, and the controlling procedure and methods, criteria of performance evaluation of audit firms, and public control over audit have not been clarified enough in Latvian official documents.

The purpose of research is to develop recommendations how legislation, methodology, and organization of quality control over auditing services in Latvia may be improved.

The object of research is the system of internal and external control over audit services in Latvia.

The tasks of research:

- to analyze and evaluate the market of auditing services in Latvia;

- to identify factors influencing its development;

1 Ludmila Verovska - Baltic International Academy, Financial Department, Finances and Audit

E-mail: mila.v@inbox.lv

Tel.: +371261006 46 
- to identify and describe the concept of audit quality control, its criteria and requirements;

- to study Latvian legislation and other regulations governing the control over the quality of audit services, and to identify shortcomings;

- to develop recommendations for improvement of the quality of audit services and the efficiency of internal and external control.

The methods of research: grouping, comparison, generalization, description; the methods of analysis and synthesis of economic information: tabular, graphical, expert.

\section{Analysis of the market for audit services}

The dynamics of the market turnover of accounting and consulting services in Latvia has been continuously positive.

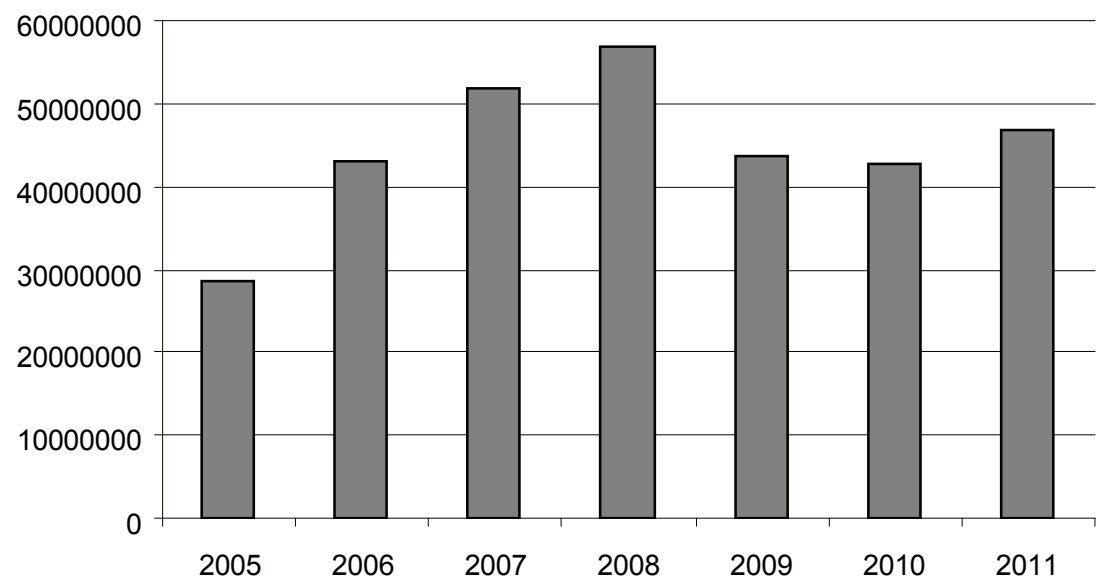

Figure 1. The turnover dynamics of the Latvian market for audit and consulting services 2005-2011 (in euro)

Source: composed by the author according to Lursoft. Availablea at: http:///www.lursoft.lv/

The most favorable period was in 2008, when the positive growth was $97 \%$ as compared with 2005 . In 2009 there was a sharp drop in the turnover - by 23, due to the economic crisis. In 2011, the situation stabilized. In 2010, the increase was $9 \%$, as compared with 2005 and $62 \%$ as compared with 2011.

The increase of audit services may be explained by several factors:

- Latvia has become a member state of EU;

- Gross domestic product has grown, industry, and retailing trade have expanded;

- A large number of companies are subject to the mandatory audit because of the low level of criteria in Latvia.

The criteria for mandatory audit are the following: the value of property should amount to 0.36 million euro, revenues -0.71 million euro, the number of people employed should be 25 .

For comparison, in Lithuania, these figures are much higher: the value of property should be 1.45 million euro, revenues -2.9 million euro, number of employees -50 .

This difference upsets the balance of the competitive environment in the Baltic region, not only in the field of auditing, but also increases the administrative costs of national firms, which are forced to conduct a mandatory audit being not large enough companies by international standards.

The sector of audit services in Latvia is dominated by five major players: Ernst\&Young Baltic; KPMG Baltics; Pricewaterhouse Coopers; Deloitte Latvia, Ltd. and Deloitte Audits Latvia, Ltd.; and BDO Invest 
Rìga, Sworn Advocate Bureau, BDO Zelmenis\&Liberte. Figure 2 shows the market share of auditing services, occupied by each of these companies in the total amount of auditing and consulting services.

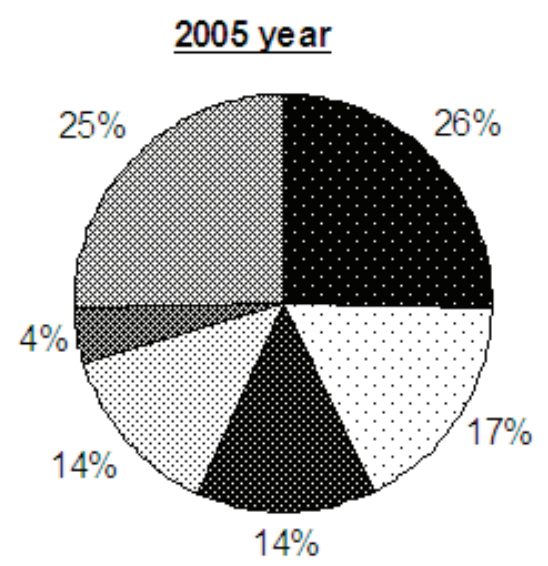

2011 year

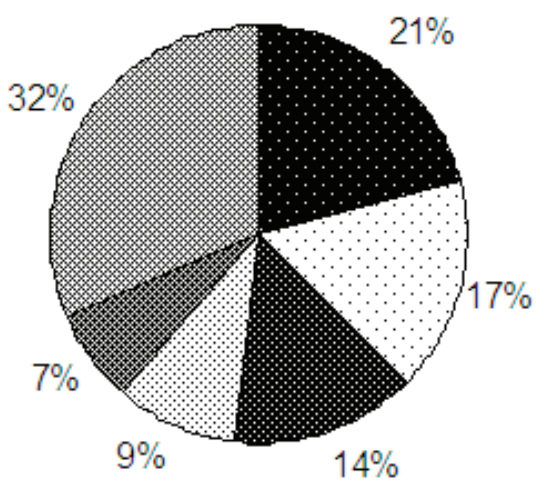

2010 year

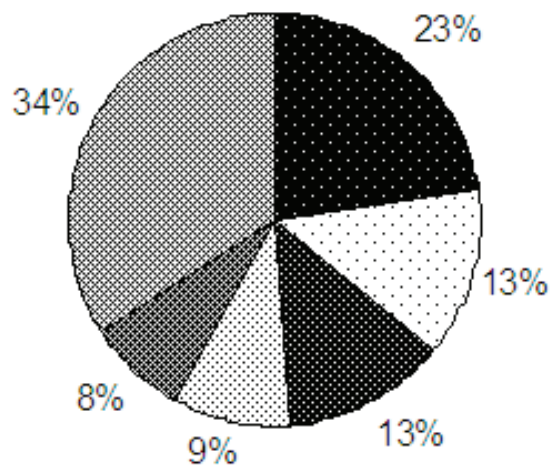

Enst\&Young Baltic

๑ KPMG Baltics

Pricew aterhouseCoopers

ㅁoloitte Latvia SIA, Deloitte Audits Latvia SIA

圈 BDO Invest Riga, Sw orn Adv oc ate Bureau BDO Zelmenis \&Liberte

图 Other

Figure 2. Market shares of five major auditor companies in Latvia in 2005, 2010 and 2011 (\%)

Source: composed by the author according to Lursoft. Available at: http:///www.lursoft.lv/

The figure shows that the largest share of the market was occupied by four major international companies and one national company "BDO Invest Rīga". Although in comparison with 2005 (75\%) their shares decreased, they still dominated the most of the market. In 2010, their combined share was $66 \%$, and in $2011-$ $68 \%$. The largest share of the market belonged to Ernst \& Young Baltic, which was $23 \%$ in 2010 and $21 \%$ in 2011. The process of capital concentration has not bypassed the spheres of audit and consulting services. A high degree of monopolization in the sphere of audit is typical for Latvia as well. At one and the same time a large number of small firms ( $75 \%$ ) with a turnover of less than 120 thousands euro are active on the market of auditing services, which is not conducive to effective control over the quality of their services.

The profit share of these companies was $39.22 \%$ in 2010, and $46.69 \%$ in 2011 . The share of employees in these companies was $37.26 \%$ in 2010, and $39.52 \%$ in 2011.

The current market structure has established itself in its present form due to several reasons. One of them is that foreign subsidiaries prefer to choose a well-established international auditing company, and sometimes come to the Latvian market, together with already existing connections of its parent company in the field of audit. Another reason refers to a high threshold of insurance costs due to the customers' value of assets, which does not allow domestic companies to participate in the audit of banks, insurance and listed companies. And finally, the scarcity of historical experience of national auditor companies, insufficient financial resources and limited opportunities in the development of their own methodological basis, do not contribute to the development of the national brand with international reputation. 
Table 1. Economic performance of auditor companies for the period of 2010-2011

\begin{tabular}{|l|l|l|l|l|l|l|}
\hline \multirow{2}{*}{} & \multicolumn{2}{|c|}{ Turnover (in euro) } & Number of employees & \multicolumn{2}{c|}{ Profit (in euro) } \\
\cline { 2 - 8 } & \multicolumn{1}{|c|}{$\mathbf{2 0 1 1}$} & $\mathbf{2 0 1 0}$ & $\mathbf{2 0 1 1}$ & $\mathbf{2 0 1 0}$ & $\mathbf{2 0 1 1}$ & $\mathbf{2 0 1 0}$ \\
\hline Ernst\&Young Baltic & 9669521 & 9804284 & 49 & 47 & 1006963 & 1592807 \\
\hline KPMG Baltics & 7871429 & 5594140 & 87 & 79 & 412143 & 63357 \\
\hline PricewaterhouseCoopers & 6760227 & 5586109 & 81 & 88 & 656130 & 97739 \\
\hline $\begin{array}{l}\text { Deloitte Latvia SIA, Deloitte Audits } \\
\text { Latvia SIA }\end{array}$ & 4366719 & 3923056 & 60 & 50 & 100087 & -24029 \\
\hline $\begin{array}{l}\text { BDO Invest Riga, Sworn Advocate } \\
\text { Bureau BDO Zelmenis\&Liberte }\end{array}$ & 3340186 & 3366687 & 51 & 49 & 585784 & 486980 \\
\hline Other & 14710160 & 14585770 & 502 & 527 & 3152419 & 3436210 \\
\hline Total: & $\mathbf{4 6 7 1 8 2 4 1}$ & $\mathbf{4 2 8 6 0 0 4 6}$ & $\mathbf{8 3 0}$ & $\mathbf{8 4 0}$ & $\mathbf{5 9 1 3 5 2 6}$ & $\mathbf{5 6 5 3 0 6 4}$ \\
\hline
\end{tabular}

Source: the author's calculations based on "Lursoft". Available at: http://www.lursoft.lv/

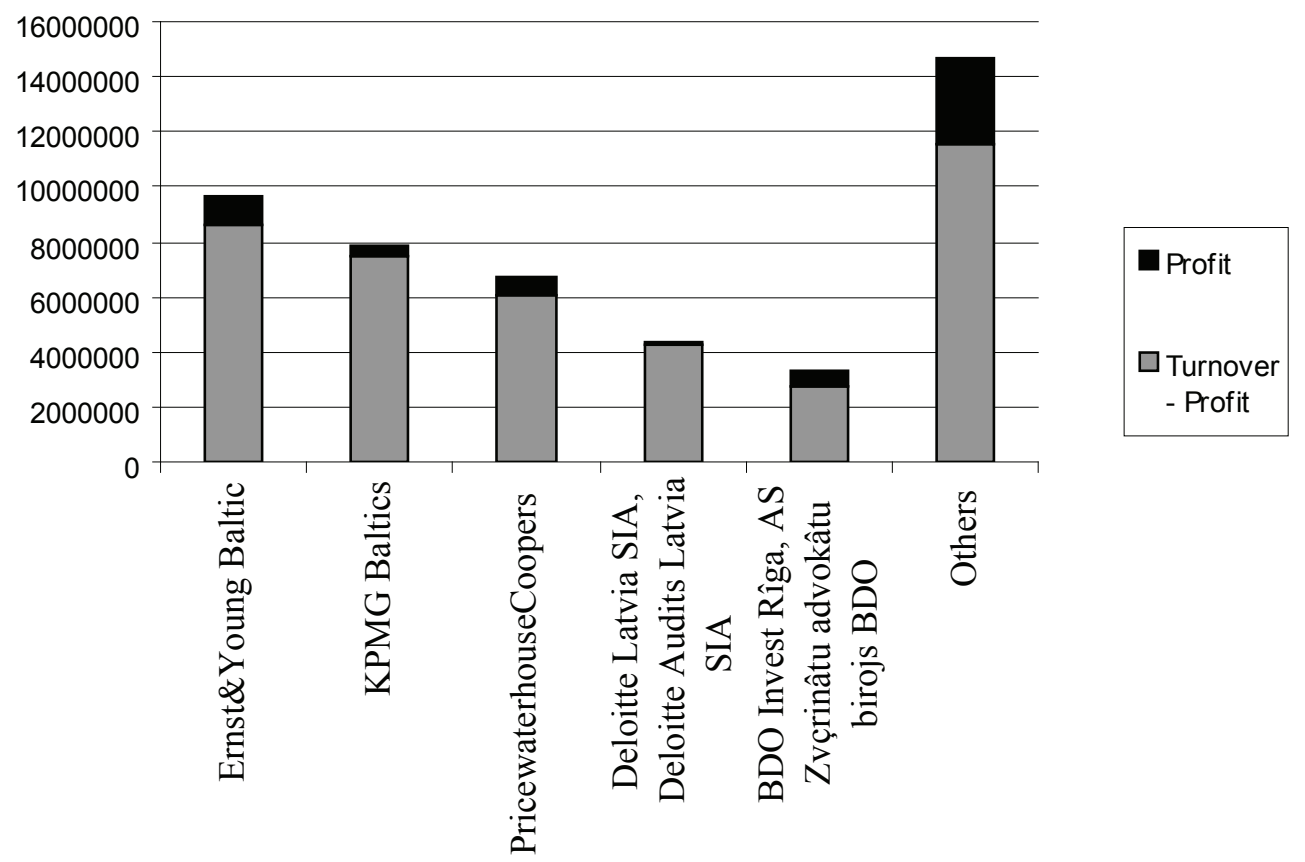

Figure 3. Profit share in the turnover of auditor companies in 2010 (in euro)

Source: composed by the authors according to Lursoft. Available at: http://www.lursoft.lv/

Regarding the assessment of profit it should be noted that its share in the overall turnover decreased from $13.19 \%$ to $12.66 \%$ in 2011 compared to 2010 . This applies to all four international companies. However, local firms worked more efficiently (the firms included in the group designated as "others"). The profit share of "BDO Invest Rīga" in 2011 increased to $17.54 \%$ (against 14, $46 \%$ in 2010). 


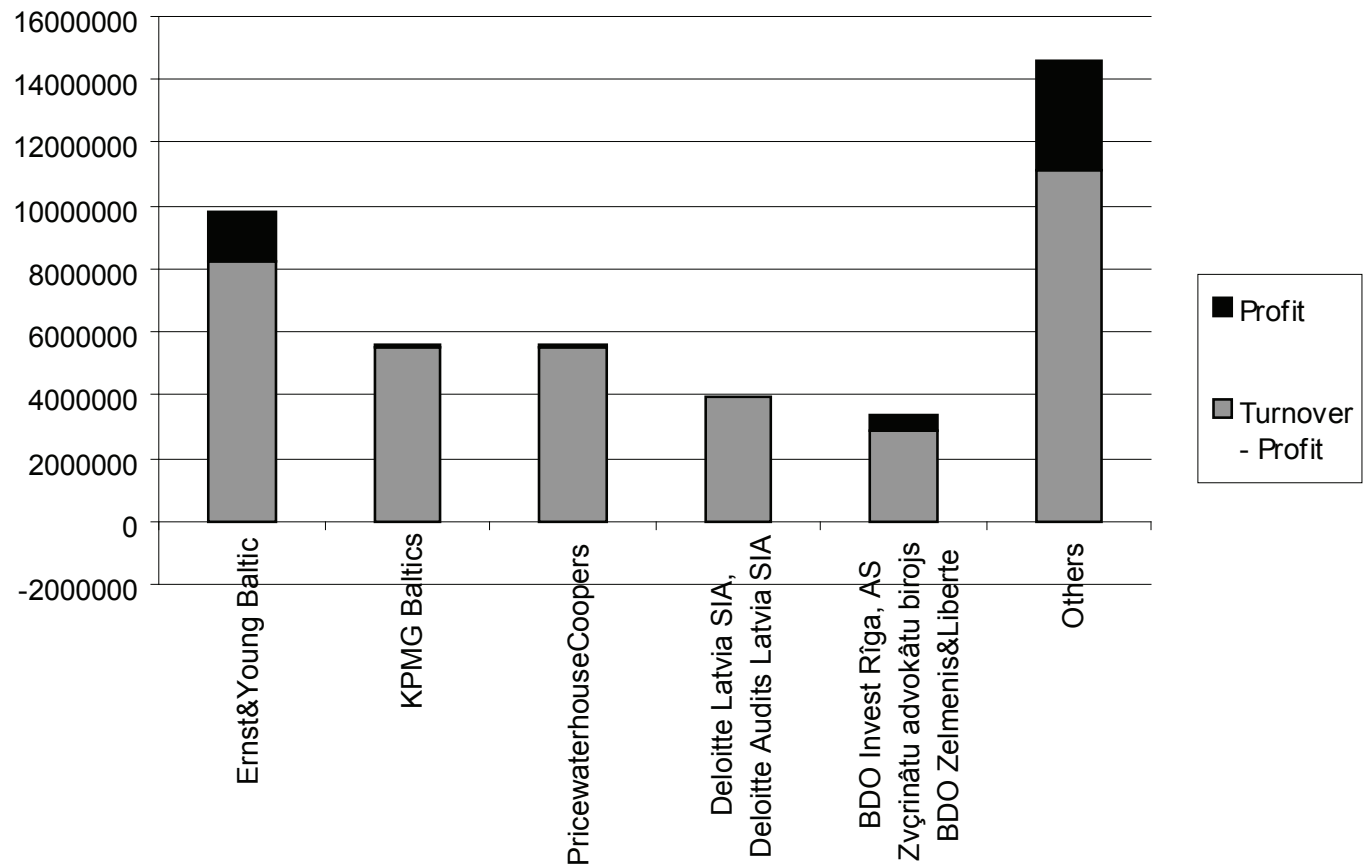

Figure 4. Profit share in the turnover of auditor companies in 2011 (in euro)

Source: composed by the authors according to Lursoft. Available at: http:///www.lursoft.lv/

\section{International regulation of audit quality control}

In the international practice, the basic document that regulates the quality standards of professional services is the statement of membership obligations 1 "Quality assurance" accepted by IFAC (International Federation of Accountants). This document prescribes the requirements to the quality of auditing services performed by the auditors' professional associations. Quality requirements at the level of audit companies are regulated by the International Standard of quality control 1 "Quality control for firms that perform audits and reviews of other assurance and related services engagements". Quality requirements to individual audit assignments are regulated by the International Standard of auditing 220R "Quality control for audits of historical financial information". For the provision of practical assistance in understanding and application of quality control standards in a particular firm and in accomplishment of a particular assignment, the following document is applied: "JFAC Request for Proposal: Development of a Guide to Quality Control for use by Small and Medium Practices”.

\section{Definition of audit quality and its control as terms}

The International organization of standardization (ISO) defines quality as a degree of customer's satisfaction. This leads to conclusion that audit is meant to satisfy the need of the society in reliable financial information.

According to International Auditing Standard N220, a quality audit is the audit conducted in accordance with International Standards on Auditing. Given that international standards have a general nature, it is necessary to clarify the criteria of an expert high-quality audit. These criteria include the compliance with:

1. International standards of audit and directives of EEK.

2. Regulations of LR Law "On Sworn Auditors".

3. Standards of professional ethics.

4. Terms and requirements of the license. 
5. Regulations of LR Cabinet of Ministers and the internal rules of Latvian Association of Certified Auditors.

6. Internal regulations of an auditing company (consistent with international standards and rules of the Association.)

7. Terms of a contract for audit services.

The system of quality control is understood as a system of policies, practices, and procedures adopted by the auditing company so that its management and the society in general had a reasonable assurance that auditing services are performed according to international standards, codes of professional ethics, regulation documents defining auditing practice in Latvia, and the provisions accepted by the Association of Certified Auditors.

The quality control of auditing services is carried out by methods providing assurance that the company is fulfilling its obligations to its customers in the best way. The quality of audit depends on the organizational structure of the company-auditor and on the choice of auditing procedures that guarantee compliance with generally accepted auditing standards appropriately selected for each client. An appropriate organizational structure includes expert professionals educated in essential features of the client's technological production. Each auditing company should establish policies and procedures of inspection, which will depend on the size of the audited firm, its international and national status, the number of offices and clients, their diversity, and the type of practices.

The quality control should include certain features (Table 2).

Table 2. Features of audit quality control

\begin{tabular}{|l|l|}
\hline \multicolumn{1}{|c|}{ Feature } & \multicolumn{1}{c|}{ Compliance with the quality requirements } \\
\hline Independence & $\begin{array}{l}\text { Auditors and other personnel involved in the audit should comply with the requirements to } \\
\text { independence prescribed by the Code of Ethics accepted by LASA and the Law on "Sworn } \\
\text { Auditors" }\end{array}$ \\
\hline Professional status & $\begin{array}{l}\text { Personnel involved in the audit, should be sufficiently knowledgeable in the client's } \\
\text { production technology, and have relevant education and expertise. A new candidate should } \\
\text { be approved by a competent, qualified specialist responsible for the staff. The professional } \\
\text { expertise of the staff should be developed on an ongoing basis. Career promotions should } \\
\text { correspond to qualifications }\end{array}$ \\
\hline $\begin{array}{l}\text { Availability of } \\
\text { consultations }\end{array}$ & $\begin{array}{l}\text { In cases when technical problems concerning the implementation of audit engagements arise, } \\
\text { the participating auditors should have an opportunity to be advised by relevant qualified } \\
\text { professionals }\end{array}$ \\
\hline Policy of control & $\begin{array}{l}\text { The policy of control should be observed at each inspection, and at all levels and stages such } \\
\text { as planning, auditing, preparation of the conclusion and reporting to the management }\end{array}$ \\
\hline $\begin{array}{l}\text { Procedures of } \\
\text { control }\end{array}$ & $\begin{array}{l}\text { The procedures of control applied by the auditing firm should meet all the requirements to } \\
\text { quality and have the features of quality, the whole process being supervised by a responsible } \\
\text { person }\end{array}$ \\
\hline
\end{tabular}

Source: completed by the author on the basis of the Statement on Auditing Standarts - SAS, issued by AICPA (American Institute of Certificed Public Accountants)

The auditing firm should systematize, approve and confirm the principles and procedures of control in accordance with the features of control.

4. Oversight and control of the activities and quality of auditing services provided by certified auditors and commercial auditors' associations of Latvia

Problems related to the organization of audit quality control in Latvia are regulated by Article 35 of the "Law on Sworn Auditors". According to this Law, a three-tier system of audit quality control is accepted in Latvia: 
- State control exercised by the Ministry of Finance.

- Professional control exercised by Latvian Association of Certified Auditors (LASA).

- Quality control carried out by audit firms and individual certified auditors.

Table 3. The structure of audit quality control in Latvia

\begin{tabular}{|l|l|l|l|}
\hline Form of control & \multicolumn{1}{|c|}{ Subjects of control } & \multicolumn{1}{|c|}{ Objects of control } & \multicolumn{1}{c|}{ Type of control } \\
\hline \multirow{2}{*}{ External control } & Ministry of Finance & $\begin{array}{l}\text { Latvian Association of Certified } \\
\text { Auditors, audit firm, certified } \\
\text { auditor * }\end{array}$ & $\begin{array}{l}\text { Control over compliance and } \\
\text { efficiency }\end{array}$ \\
\cline { 2 - 4 } Internal control & $\begin{array}{l}\text { Association of Certified } \\
\text { Auditors }\end{array}$ & $\begin{array}{l}\text { Audit firm, certified auditor, a } \\
\text { separate audit engagement } \\
\text { certified auditor }\end{array}$ & $\begin{array}{l}\text { Control over compliance, } \\
\text { efficiency and substantive control }\end{array}$ \\
\hline a separate audit engagement & $\begin{array}{l}\text { Control over compliance, } \\
\text { efficiency and substantive control }\end{array}$ \\
\hline
\end{tabular}

* A separate audit assignment on the audit of a listed company

Source: Authors' interpretation

\section{Auditing services quality control exercised by the state and LASA}

The purpose of quality control is to provide reasonable assurance that an audit firm has created the internal quality control system, adheres to its requirements, and observes professional standards, ethical principles, and legal acts of Latvian Republic. The decision of which entity and how often to check depends on many factors. In practice, two approaches are accepted: time-domain and risk-based. The first approach sets the maximum periodicity of inspections. The second approach takes into account such factors as the number of listed corporate clients, socio-economic value of companies, and the history of violations registered in previous inspections. In Latvia, both approaches are used: the time-domain and risk-based for listed companies.

All commercial companies of sworn auditors and individual sworn auditors are subject to the quality control at least once every five years. Those commercial companies of sworn auditors and sworn auditors that provide services to financial institutions and commercial companies whose securities are admitted to the regulated market of the member states are subjected to the quality control at least once every three years.

Quality inspection of auditing services is performed in accordance with regulations approved by LASA in coordination with the Ministry of Finance. A month before the commencement of the quality inspection, LASA notifies the Ministry of Finance which sworn auditors or commercial companies of sworn auditors are subject to inspection at least once every three years.

To date, the functional responsibilities of the Latvian Association of Certified Auditors have not included the development and implementation of the auditing methodology. According to Paragraph 4, Article 6 of the Law "On Sworn Auditors", the Association:

- provides oversight of compliance with professional standards and ethical principles, as well as other relevant regulations governing the profession and supervises professional activity of the members of the Association;

- represents and protects the interests of its members;

- conducts qualification inspections of sworn auditors;

- decides on the issuance of certificates to sworn auditors and on granting licenses to commercial companies of sworn auditors;

- keeps the register of sworn auditors and the register of commercial companies of sworn auditors;

- adjudicates disputes that may arise between sworn auditors and their clients upon the request of the parties involved;

- organizes and oversees the professional development of sworn auditors. 
Up to date, functional responsibilities of the Latvian Association of Certified Auditors do not include the development and implementation of inspection methodology of the audit conduct.

The standards of audit represent general guidance aimed to direct auditors in the performance of their professional duties. These standards should not be the sole source of guidance for audit practitioners. Taking into account national peculiarities of the audit services market, scant historical experience in the development of audit in Latvia, and the level of foreign languages known by auditors, there is a great demand in the educational and methodological materials, explaining the auditing standards and practices in greater detail.

The Ministry of Finance exercises official state supervision over the Latvian Association of Certified Auditors and cooperates with institutions competent in the field of audit in other member states and third countries. LASA approves all legal documents related to certification, licensing, and implementation of other tasks upon agreement with the Ministry of Finance. Direct supervision is exercised by the authorized representative of the Ministry of Finance. They are entitled to participate in board meetings and general meetings, to get acquainted with the decisions of the association, to require all information, documents and explanations for supervision. The authorized representatives of the Ministry of Finance check the compliance of auditing services with the quality control and prepare a corresponding report at least once a year. They have the right to conduct inspections of the quality control at the place of practice of a certified auditor or a commercial company of sworn auditors, if the client is a financial institution or a commercial company whose securities are admitted to the regulated market of the member states. This right also involves inspection of audit related working papers and the public statements of a sworn auditor or a commercial company of sworn auditors. In order to respect the principle of independence such authorized representatives should meet a number of requirements: they cannot provide auditing services for three years prior to a new job, they cannot be shareholders, nor members of the Board or Council, nor be employed by a commercial company of certified auditors and they shall keep commercial secrets, except in the cases established by the law.

The Cabinet of Ministers (CM) establishes the Auditing Advisory Council. Its goal is to improve the quality of auditing services. The Ministry of Finance, the Ministry of Justice, the Committee of the Market of Finance and Capital, Latvian Association of Certified Auditors, Riga Stock Exchange, the Council of Foreign Investors in Latvia, Latvian Association of Accountants, Latvian Confederation of Employers and one of Latvian higher education institutions, each provide one representative as a member for the Council. The membership of the Council is approved by the CM and the Council acts on the basis of the approved regulations. Its activities are funded from the state budget. The Council considers documents prepared by LASA on the subject of implementation of examinations, certifications, licensing, professional development of certified auditors and quality control. Also the Council studies international auditing standards and ethical principles recognized in Latvia, makes recommendations to LASA for their application and informs the Ministry of Finance. To achieve its objectives the Council has the right to demand information from LASA and the necessary documents, and also to attend LASA meetings and sessions. The Council informs the Ministry of Finance on the performed activities once a year.

The public oversight of audit quality is very weak. This is mainly due to the lack of public information, the lack of clear legal regulations to its provision by the Association and commercial companies, and the insufficiency of provided information. The law "On Sworn Auditors" demands from sworn auditors to report publicly on their electronic home pages. These reports should provide general information on the main features of the system of internal quality control and the statement of the management on the efficiency of this system, also information on when the last time the external control was conducted. However, this requirement applies only to those auditors, who check listed companies. The Association of Certified Auditors annually provides a report on quality control, which is a mere formality providing just numbers of inspections and numbers of detected violations. This situation is not conducive to public scrutiny and a thorough implementation of the system of audit quality control in the national scale. 


\section{Conclusions}

The unsustainable development of Latvian economy, the increase in information risk and the need to attract foreign investments make high demands to the reliability and quality of corporate financial statements, confirmed by professional independent experts. The system of audit quality control depends on many factors, including the degree of development of the national legislation, the techniques and the ability to learn and effectively apply the unified international audit regulating rules and standards.

The market of auditing services in Latvia is developing, but has not reached the pre-crisis level yet. The market is characterized by the dominant position of the four largest international companies: Ernst\&Young Baltic; KPMG Baltics; PricewaterhouseCoopers; Deloitte Audits Latvia, Ltd. At one and the same time a large number of small firms, which is not conducive to effective control over the quality of their services.

The article specifies the terms: the system of audit quality control, professional audit and its criteria, elements of quality control.

The analysis of the legislative framework governing audit services in Latvia revealed certain deficiencies of the external control at the state level, at the level of the Association of Certified Auditors, and at the level of public control; and factors that are not conducive to the development of the efficient system of audit quality control.

The system of audit quality inspection ad control in Latvia may be improved in the following ways:

- in order to improve and create a modern methodological support of the audit inspection procedure, certain amendments should be introduced to LR legislation; Latvian Association of Certified Auditors should be entrusted with the duty to develop software-based methods of audit inspection conduct. To amend Article 6 Paragraph 4 of the Law "On Sworn Auditors" and to oblige the Association of Certified Auditors to develop methodological materials for the audit control and to assist in their application by Latvian companies;

- in order to improve the system of public oversight, the amount of information on violations revealed by the Association should be expanded and not limited only by the description of the number of inspections and the number of detected violations;

- Latvian Association of Certified Auditors should contribute to the development and improvement of the performance of national companies active in the market of auditing services in Latvia, and help these companies to improve the quality of service by means of effective application of international experience;

- National requirements to auditing services should be developed and applied reasonably, in an objective and impartial manner. Specific requirements should not create unnecessary barriers. In this regard, the statutory audit criteria for Latvian companies should be extended to the level accepted in the Baltic region (Lithuania). This will affect the market of audit services by reducing the number of small firms, but at the same time will allow controlling the quality of audit in a more efficient way.

The improvement of audit quality control facilitates the promotion of professional services in the Latvian market of auditing services; enhances professional advancement of auditors and improves their professional reputation; optimizes the auditing services market by way of reducing the number of non bona fide auditor firms; increases the number of services rendered in the international market, attracts foreign clients with offices in Latvia, minimizes business risk and maximizes international investments; improves business environment and the national image of the country; and in overall contributes to the stable development of the national economy. 


\section{References}

Likums "Par zvērinātiem revidentiem". Available at: www.likumi.lv

Direktīva 84/253/EEK. Available at: http://eur-lex.europa.eu/LexUriServ/LexUriServ.do?uri=DD:17:01:31984L0253: $\mathrm{LV}: \mathrm{PDF}$

Direktīva 2006/43/EK. Available at: http://eur-lex.europa.eu/LexUriServ/LexUriServ.do?uri=OJ:L:2006:157:0087:01 07:LV:PDF

Statements of Membership Obligations 1 “Quality Assurance” IFAC.

International standard on quality control 1 "Quality Control for Firms that Perform Audits and Reviews of Financial Statements, and Other Assurance and Related Services Engagements".

International Standard on Auditing 220R "Quality Control for Audits Historical Financial Information”. Request for proposal: Development of a Guide to Quality Control for use by Small and Medium Practices.

Arens, A. A., Elder, R. I., Beasley, M. S. (2003). Auditing and assurance services an intergrated approach. 9th ed. Prentice Hall, 765 p.

Internal Control Working Party, Internal Control: Guidance for Directors on the Combined Code. (1999). London: The Institute of Chartered Accountants in England \& Wales.

Latvian information technology company. Available at: www.lursoft.lv

Ministru kabineta 27.12.2001. noteikumi Nr. 547 "Noteikumi par zvērināta revidenta - pašnodarbinātas personas vai individuāla komersanta - un zvērināta revidentu komercsabiedrības civiltiesiskās atbildības apdrošināšanas minimālo atbild̄̄bas limitu”. Available at: www.likumi.lv

Ministru kabineta 08.06.2004. noteikumi Nr. 525 "Kārtība, kādā iesniedzami pieteikumi un citi dokumenti zvērinātu revidentu kvalifikācijas eksāmenu kārtošanai un zvērinātu revidentu komercsabiedrības licences saņemšanai”. Available at: www.likumi.lv

Адамс, Р. (2006). Основы аудита (пер. с англ.). Москва: Финансы и статистика.

Аренс, А. А., Лоббек, Дж. К. (2003). Аудит (пер. с англ.). Москва: Финансы и статистика, 558 с.

Дефлиз, Ф. Л., Дженик, Г. Р., О’Рейли, В. М., Хирш, М. Б. (1997). Аудит Монтгомери (пер. с англ.). Москва: Аудит, ЮНИТИ, 542 с.

Мантгомери, Ф., Дефлиз, Л., Дженик, Р. Д., О’Рейлли, В. М., Хирш, М. Б. (1997). Аудит (пер. с англ.). Москва: Аудит: ЮНИТИ.

\section{LATVIJOS AUDITO PASLAUGU SISTEMOS TOBULINIMAS}

LUdMILA VEROVSKa

Tarptautinė Baltijos akademija (Latvija)

Santrauka

Audito veikla - tai paslaugu rūšis, todèl audito neįmanoma plètoti nepaisant paslaugu sektoriuje vyraujančių tendencijų. Tarptautinès audito paslaugų rinkos su vieningomis taisyklèmis, standartais ir kokybės kriterijais sukūrimas yra strateginè audito paslaugu plètros kryptis. Šiame straipsnyje nagrinèjama audito paslaugu koncepcija, tiriamos pagrindinès teisinès ir metodologinès išorinio bei vidinio audito Latvijoje problemos, remiantis tarptautine patirtimi, pateikiami Latvijos audito paslaugų sistemos tobulinimo būdai. Tyrimo rezultatai gali būti panaudoti kuriant ir tobulinant vidinio bei išorinio audito sistemas, kurios pateiktu patikimus duomenis apie verslo būklę ir jo plètros perspektyvas. Bendrovès finansinis stabilumas, patvirtintas nepriklausomo auditoriaus objektyvia nuomone, skatina investicijų augimą, didina akcijų kainą, gerina bendrovès reputaciją finansinèse rinkose ir galiausiai prisideda prie stabilaus viso regiono vystymosi.

PAGRINDINIAI ŽODŽIAI: audito kokybès sistema, kokybès kriterijai, vidine ir išorinè kokybès kontrolè.

JEL KLASIFIKACIJA: M42; M41; D63 